JURNAL SELAT

Volume. 8 Nomor. 1, Oktober 2020. p - 2354-8649 I e - 2579-5767

Open Access at: http://ojs.umrah.ac.id/index.php/selat

DOI: https://doi.org/10.31629/selat.v8i1.2198

\title{
IMPLIKASI SENGKETA BATAS WILAYAH TERHADAP PENYELENGGARAAN PEMILU (Studi Kasus di Provinsi Maluku Utara)
}

\author{
Sultan Alwan \\ Fakultas Hukum Universitas Khairun \\ Kampus II Gambesi, Ternate, 97719 \\ sul_alwan3@yahoo.com
}

\begin{abstract}
Area expansion as a consequence of regional autonomy implementation has caused excess regional boundary disputes which led to conflicts. The case that occurred in six villages in the North Maluku Province was due to the refusal of residents to be part of the District in North Halmahera Regency and wanted to remain in the West Halmahera Regency. In reality there is a dualism in government administration services because each village has two Village Heads, namely the North Halmahera government and the West Halmahera government version. The dissolution of disputes settlement has implications for the implementation of Regional Head Elections and Elections in the region. Election Organizers stipulate that the Permanent Voters List (DPT) of six villages is included in the jurisdiction of North Halmahera Regency. As a form of protest, thousands of citizens did not exercise their right to vote in the 2014 and 2018 Regional Head Elections. The General Election Law and Regional Head Election at present, it has not explicitly regulated the guarantee of the protection of citizens' rights to vote in the area of boundary disputes due to the division of regions. In the future, special arrangements need to be made so that no citizen loses his right to vote because of technical administrative issues that ignore the election substance.
\end{abstract}

Keywords; Right to Vote, Dispute Territory, General Elections.

\begin{abstract}
Abstrak
Pemekaran wilayah sebagai konsekwensi logis dari pelakasanaan otonomi daerah telah menimbulkan ekses sengketa batas wilayah yang berujung konflik. Kasus yang terjadi di 6 (enam) desa dalam wilayah Maluku Utara disebabkan karena adanya penolakan warga menjadi bagian dari Kecamatan dalam wilayah Kabupaten Halmahera Utara dan menginginkan tetap dalam wilayah Kabupaten Halmahera Barat. Pada kenyataannya terjadi dualisme pelayanan administrasi pemerintahan karena masing-masing Desa terdapat 2 (dua) orang Kepala Desa yakni versi pemerintah Halmahera Utara dan versi pemerintah Halmahera Barat. Berlaurutnya penyelesain sengketa berimplikasi pada penyelenggaraan Pemilihan Kepala Daerah dan Pemilu di wilayah tersebut. Penyelenggara Pemilu menetapkan Daftar Pemilih Tetap (DPT) warga 6 (enam) desa masuk dalam yurisdiksi Kabupaten Halmahera Utara. Sebagai bentuk protes, ribuan warga tidak menggunakan hak pilihnya pada Pemilu dan Pemilihan Kepala Daerah Tahun 2014 dan 2018. Undang-undang Pemilu dan Pilkada yang ada saat ini, belum mengatur secara eksplisit terkait jaminan
\end{abstract}


perlindungan hak warga negara untuk memilih (right to vote) di wilayah sengketa batas akibat pemekaran wilayah. Kedepan perlu pengaturan khusus agar tidak ada warga negara yang kehilangan hak pilihnya karena persoalan teknis admnistrasi yang mengabaikan substansi berpemilu.

Kata Kunci; Hak untuk Memilih, Pemilihan Umum, Sengketa Wilayah.

\section{PENDAHULUAN}

Sejak diakomodirnya aspirasi mengenai otonomi daerah dan desentrlisasi telah menimbulkan perubahan mendasar pada hubungan antara pemerintah pusat dan daerah yang sebelumnya sangat sentralistik ${ }^{1}$. Pemberian otonomi yang seluasluasnya kepada daerah diarahkan untuk mempercepat terwujudnya kesejahteraan masyarakat melalui peningkatan pelayanan, pemberdayaan, dan peran serta masyarakat. Disamping itu melalui otonomi luas, daerah diharapkan mampu meningkatkan daya saing dengan memperhatikan prinsip demokrasi, pemerataan, keadilan, keistimewaan dan kekhususan serta potensi dan keanekaragaman daerah dalam sistem Negara Kesatuan Republik Indonesia². Sejalan dengan itu, kebijakan yang dibuat dan dilaksanakan oleh daerah merupakan bagian yang integral dari kebijakan nasional.

Salah satu aspek penting dalam otonomi darah adalah penataan daerah dan dibukanya kran bagi daerah untuk melakukan pembentukan Daerah Otonomi Baru (DOB). Euforia reformasi dan demokrasi muncul tuntutan untuk berlomba-lomba mengusulkan pemekaran daerah ${ }^{3}$. Laju perkembangan pemekaran wilayah yang sangat cepat, pada tahun 2014 dikeluarkanlah kebijakan moratorium pemekaran daerah. Data menunjukkan terdapat 314 usulan DOB di seluruh Indonesia yang sampai saat ini masih ditangguhkan oleh Kementerian Dalam Negeri ${ }^{4}$. Kedepan tidak menutup kemungkinan usulan pemekaran daerah akan semakin meningkat seiring dengan kesadaran masyarakat menuntut pemerataan pembangunan dan keadilan guna mewujudkan kesejahteraan masyarakat.

\footnotetext{
${ }^{1}$ Ni'matul Huda, Hukum Pemerintahan Daerah, Bandung: Nusa Media, 2017, hlm. 92.

2 Penjelasan Umum atas Undang-Undang Republik Indonesia Nomor 9 Tahun 2015 tentang Perubahan Kedua Atas Undang-Undang Nomor 23 Tahun 2014 tentang Pemerintahan Daerah.

3 Istilah Pemekaran Daerah mulai dikenal pada Undang-Undang Republik Indonesia Nomor 22 Tahun 1999 tentang Pemerintahan Daerah. Istilah pemekaran dapat dilihat pada Pasal 5 ayat (2) yang menyatakan bahwa Daerah dapat dimekarkan menjadi lebih dari satu Daerah.

4 "Pemerintah Moratorium DOB hingga 2019", diakses pada tanggal 22 September 2018.
} 
Pelaksanaan pemekaran daerah bukan tanpa masalah, terdapat fakta memperlihatkan banyak DOB gagal memenuhi syarat esensial tujuan didirikannya pemerintahan daerah baru, yakni meningkatkan kesejahteraan masyarakat. Menurut Siti Zuhro, ada banyak tantangan dan persoalan berat yang umumnya dihadapi DOB salah satunya adalah persoalan batas wilayah atau konflik perbatasan ${ }^{5}$. Munculnya sengketa batas wilayah telah menimbulkan masalah yang berdampak pada terganggunya tatanan masyarakat (sosial, budaya, ekonomi dan politik) yang berpotensi muncul konflik yang bersifat struktural maupun horizontal.

Salah satu contoh sengketa ${ }^{6}$ akibat DOB adalah wilayah 6 (enam) Desa ${ }^{7}$ antara Kabupaten Halmahera Barat dengan Kabupaten Halmahera Utara Provinsi Maluku Utara. Sengketa batas wilayah di 6 (enam) Desa telah berlangsung cukup lama, sejak dikeluarkannnya Peraturan Pemerintah Nomor 42 Tahun 1999 tentang Pembentukan dan Penataan Beberapa Kecamatan di Wilayah Kabupaten Daerah Tingkat II Maluku Utara dalam wilayah Provinsi Daerah Tingkat I Maluku Pembentukan Kecamatan Makian Malifut yang memasukan 6 (enam) Desa dari Kecamatan Jailolo dan 5 (lima) Desa di Kecamatan Kao. Sejak saat itu telah terjadi penolakan masyarakat 6 (enam) Desa Kecamatan Jailolo. Penolakan tersebut tidak mendapat respon dari Pemerintah saat itu, yang menyebabkan konflik berkepanjangan9. Tensi penolakan warga semakin tinggi ketika disahkannya UU Nomor 1 Tahun 2003 yang mengatur pembentukan 4 (empat) kabupaten yakni: Kabupaten Halmahera Utara, Kabupaten Halmahera Selatan, Kabupaten Kepulauan Sula dan Kabupaten Halmahera Timur, serta Kota Tidore Kepulauan. Sedangkan Kabupaten Maluku Utara (Kabupaten Induk) berubah nama menjadi Kabupaten Halmahera Barat Ibu Kotanya Jailolo. Penegasan kembali dalam UU ini bahwa Kabupaten Halmahera Utara yang wilayahnya termasuk Kecamatan Malifut yang

\footnotetext{
5 R. Siti Zuhro, Pemekaran Daerah: Antara Jimat dan Syahwat Politik (Media Indonesia, Edisi 6 Mei 2013) dalam Lukman Santoso Az, Hukum Pemerintahan Daerah: Mengurai Problematika Pemekaran Daerah Pasca Reformasi di Indonesia, Yogyakarta: Pustaka Pelajar, 2014, hlm. 210.

6 Istilah sengketa sering dipadankan dengan istilah konflik, keduanya merupakan konsep yang sama mendeskripsikan situasi dan kondisi dimana orang-orang sedang mengalami perselisihan yang bersifat faktual maupun perselisihan-perselisihan yang ada pada persepsi mereka saja. Lihat Takdir Rachmadi, Mediasi Penyelesaian Sengketa Melalui Pendekatan Mufakat, Jakarta: Raja Grafindo Persada, 2011, hlm. 1-3.

7 Desa yang terlibat perselisihan batas yakni: Desa Pasir Putih, Desa Bobane Igo, DesaTetewang, Desa Akelamo Kao, Desa Akesahu, dan Desa Dum-Dum.

8 Saat itu Maluku Utara masih berstatus Kabupaten kemudian dimekarkan menjadi Provinsi Maluku Utara dengan Undang-Undang Republik Indonesia Nomor 46 Tahun 1999.

9 Jembris Mou, "Konflik Wilayah Antara Kabupaten Halmahera Utara Dengan Kabupaten Halmahera Barat", Political Jurnal, Vol. 4, No. 1 Tahun 2015.
} 
didalamnya termasuk 6 (enam) Desa. Atas tuntutan masyarakat, maka Pemerintah Kabupaten Halmahera Barat memberikan pelayanan publik kepada masyarakat (6) Desa dengan mengeluarkan Peraturan Daerah Nomor 6 Tahun 2005 tentang Pembentukan Kecamatan Jailolo Timur yang wilayahnya meliputi 6 (enam) Desa.

Problemnya adalah Pemerintah Kabupaten Halmahera Utara memberikan pelayanan administrasi pemerintahan yang sama terhadap 6 (enam) Desa dan Kecamatan tersebut, akibatnya duplikasi pelayanan admnistrasi ${ }^{10}$, pemerintahan ${ }^{11}$, dan penganggaran ${ }^{12}$. Kondisi ini berimplikasi terhadap pelaksanaan Pemilu terutama penentuan domisili sebagai syarat menggunakan hak pilih pada Pemilu.

Penelitian Martanto ${ }^{13}$, menyimpulkan bahwa sengketa batas wilayah di daerah 6 (enam) Desa di Halmahera dipicu oleh persolan kultural masyarakat setempat dimana kontestasi ruang yang dilandasi militansi sejarah terhadap eksistensi ruang wilayah yang secara turun temurun telah dikuasai. Keberadaan politik pemekaran telah merubah situasi kehidupan masyarakat. Sedangkan Qodir dan Lakso14, sengketa batas wilayah di 6 (enam) Desa tersebut disebabkan karena tidak dilakukan studi kelayakan yang baik dan matang pada tiga faktor yakni sumber daya manusia, sumber daya alam dan pemerintahan. Sedangkan hasil penelitian Aziz Hasyim dkk ${ }^{15}$, menyimpulkan bahwa sengketa batas wilayah di 6 desa di Halmehara kerena pemekaran wilayah hanya dominan mempertimbangkan faktor politik dan kurang menyerap aspirasi masyarakat. Terlepas dari penyebab sengketa batas wilayah di 6 (enam) Desa tersebut, kondisi ini telah mengganggu pemenuhan hak masyarakat salah satunya adalah di bidang politik yakni pelaksanaan hak memilih dalam Pemilu.

Dari aspek yuridis, sebelumnya telah ada Peraturan Menteri Dalam Negeri Republik Indonesia Nomor 18 Tahun 2013 tentang Kode dan Data Wilayah

\footnotetext{
10 Pelayanan administrasi yang dilakukan oleh Aparatur Pemerintah di wilayah Kecamatan seperti pelayanan KK, KTP/E-KTP, IMB, Akta Kelahiran, dan lain-lain.

11Terdapat dualisme Pemerintahan dalam satu Kecamatan yakni 2 (dua) Kantor Camat dan Camat yang diangkat oleh Bupati Halmahera Barat dan Halmahera Utara, begitu juga dengan Kepala Desa masing-masing Desa dipimpin oleh 2 orang Kepala Desa.

12 Pemerintah Kabupaten Halmahera Barat dan Pemerintah Kabupaten Halmahera Utara menganggarkan (Budgeting) dalam APBD masing-masing.

13 Ucu Martanto, Ruang dan Konflik Wilayah: Cerita dari Enam Desa, Yogyakarta: CRCS UGM, 2012.

14 Qodir, Zuly dan Tunjung Laksono, "Politik Rente dan Konflik di Daerah Pemekaran: Kasus Maluku Utara", Working Paper No. 002/JKSG/2012.

15 Hasyim, Azis, Arya Hadi Dharmawan, dan Ambang Juanda, "Analisis Konflik Perebutan Wilayah di Provinsi Maluku Utara: Studi Kasus Perebutan Wilayah Antara Kabupaten Halmahera Barat dan Kabupaten Halmahera tentang Enam Desa", Solidarity: Jurnal Transdisiplin Sosiologi, dan Ekologi Manusia, April 2010.
} 
Administrasi Pemerintahan ${ }^{16}$, menyebutkan bahwa jumlah Kecamatan di Halmahera Barat tetap 8 karena Jailolo Timur tidak terdapat nomor induk dan status masih dalam sengketa dengan Halamehara Utara, dan untuk jumlah kecamatan di Kabupaten Halmahera Utara tetap 17 sama dengan yang diatur dalam Peraturan Menteri Dalam Negeri RI Nomor 66 Tahun 2011. Berdasarkan ketentuan tersebut maka sebenaranya Pemerintah mengakui secara de jure dan de facto terjadi sengketa di wilayah 6 (enam) Desa antara Halbar dan Halut. Terkahir pada tahun 2019 dikeluarkan Peraturan Menteri Dalam Negeri No. 60 Tahun 2019 tentang Batas Wilayah antara Halut dan Halbar diharapkan dapat menyelesaikan sengketa. Namun, DPRD dan Pemda Kabupaten Halut justru bersepakat menolak Permendagri tersebut ${ }^{17}$. Kondisi tersebut justru akan memperpanjang penyelesaian sengketa di 6 (enam) Desa.

Penyelesaian sengketa batas wilayah murni kewenangan Pemerintah. Namun, berlarutnya penyelesaian sengketa berimplikasi pada pelaksanaan penyelenggaraan Pemilu dan Pilkada. Penyelenggara Pemilu (KPU dan Bawaslu) pada setiap momentum Pemilihan seolah-oleh menjadi pihak penyebab "kegagalan" penyelenggaran pemilu di wilayah yang bersengketa.

Penolakan warga 6 (enam) Desa terhadap penyelenggara pemilu (KPU dan jajarannya) yang akan melaksanakan tugasnya terjadi sejak tahapan pendataan pemilih (pemutakhiran data) sampai tahapan pelaksanaan pemungutan penghitungan. Konflik muncul kepermukaan ditandai gejolak penolakan warga menggunakan hak pilihnya dalam wilayah Kabupaten Halmahera Utara. Warga menghendaki penyelenggaraan Pemilu dilakukan oleh penyelenggara di Kabupaten Halmahera Barat (Halbar). Sedangkan sikap penyelenggara Pemilu mengacu pada UU Pemekaran bahwa 6 (enam) Desa masuk dalam wilayah administrasi kabupaten Halmahera Utara, oleh karena itu pelayanan pendataan pemilih dan penetapan Daftar Pemilih Tetap (DPT) menjadi bagian dari wilayah Kabupaten Halamahera Utara. Namun demikian, bagi pemerintah kabupataen Halbar juga memiliki dasar hukum untuk melakukan pelayanan dan pembiayaan melalui APBD kepada

16 Terakhir diubah dengan Peraturan Menteri Dalam Negeri Nomor 137 Tahun 2017 tentang Kode dan Data Wilayah Admnistrasi Pemerintahan yang memasukkan 6 Desa pada wilayah administrasi Kecamatan Kao Teluk Kabupaten Halmahera Utara.

17 “Pemda dan DPRD Halut Sepakat Tolak Permendagri No. 60 Tahun 2019”, diakses pada tanggal 26 April 2020. 
masyarakat di 6 (enam) Desa tersebut berdasarkan Peraturan Daerah (Perda) yang memasukkan wilayah tersebut ke dalam yurisdiksi pemerintah daerah Halbar. Akibatnya masyarakat tidak terfasilitasi untuk mengunakan hak memilih pada momentum Pemilu.

Konstitusi menjamin "setiap orang berhak mendapat kemudahan dan perlakukan khusus untuk memperoleh kesempatan dan manfaat yang sama guna mencapai persamaan dan keadilan"18. Begitu pula konstitusi menjamin atas hak setiap warga atas pengakuan, perindungan, dan kepastian hukum yang adil serta perlakuan yang sama di depan hukum ${ }^{19}$.

Pada tataran praktikal sengeketa batas wilayah telah menyebabkan posisi penyelenggara pemilu delematis, disatu sisi ada kewajiban penyelenggara untuk memfasilitasi warga negara dapat menggunakan hak pilihnya secara langsung, bebas, rahasia, jujur dan adil, namun pada sisi lain peraturan teknis administrasi pemilu belum mengakomodir penyelenggaraan Pemilu di daerah sengketa batas sehingga banyak warga yang kehilangan hak pilihnya karena persoalan teknis administrasi.

Berdasarkan uraian diatas, penulis tertarik untuk menelaah bagaimana jaminan perlindungan hak memilih dalam Pemilu dan apa implikasi penyelenggaraan Pemilu dan Pilkada di 6 (enam) Desa yang bersengketa, serta bagaimana idealnya penyelenggaraan Pemilu pada daerah sengketa batas sebagai ius constituendum. Adapun yang menjadi tujuan penulisan ini untuk mengatahui dan menganalisis jaminan perlindungan hukum hak untuk memilih dalam Pemilu, menganalisis implikasi sengketa batas wilayah terhadap penyelenggaran Pemilu dan Pilkada, serta menemukan formulasi penyelenggaraan Pemilu di wilayah sengketa batas wilayah sebagai upaya perlindungan hak pilih warga negara.

\section{METODE PENELITIAN}

Jenis penelitian yang digunakan adalah penelitan socio-legal, yakni jenis penelitian selain mengkaji dan menelaah objek penelitian dari aspek hukum positif juga dilakukan kajian terhadap fakta sosial atau fenomena di masyarakat ${ }^{20}$.

\footnotetext{
18 Undang-Undang Dasar Negara Republik Indonesia Tahun 1945 (UUD NRI Tahun 1945) Pasal 29H ayat (2). 19 Pasal 28D ayat (1) UUD NRI Tahun 1945.

${ }^{20}$ Mukti Fajar ND dan Yulianto Ahmad, Dualisme Penelitian Hukum Normatif dan Empiris, Yogyakarta: Pustaka Pelajar, 2013, hlm. 46-47.
} 
Sedangkan pendekatan masalah dilakukan dengan menggunakan Undang-Undang dan pendekatan kasus. Pendekatan kasus dengan case penyelenggaraan Pemilu pada daerah sengketa batas wilayah yang dialami oleh masyarakat 6 (enam) Desa antara Kabupaten Halmahera Barat dengan Kabupaten Halmahera Utara. Jenis data yang dibutuhkan adalah data primer dan sekunder. Data primer diperoleh dari Penyelengara Pemilu KPU Kabupaten dan Bawaslu Provinsi Maluku Utara. Sedangkan data sekunder adalah berupa peraturan perundang-undangan dan Putusan Mahkamah Konstitusi. Data sekunder pendukung lainnya adalah artikel jurnal ilmiah dan berita di media online. Data yang diperolah kemudian akan uraikan secara diskriptif kualitatif dalam pembahasan guna menjawab permasalahan.

\section{PEMBAHASAN}

\subsection{Jaminan Perlindungan Hak Memilih}

UUD 1945 pasca-perubahan telah memberikan dasar-dasar penyelenggaraan negara dan penataan kehidupan berbangsa yang tercermin dari adanya pengakuan kedaulatan rakyat dan prinsip negara hukum yang demokratis ${ }^{21}$. Makna kedaulatan berada di tangan rakyat yaitu bahwa rakyat memiliki kedaulatan, tanggungjawab, hak dan kewajiban untuk secara demokratis memilih pemimpin yang akan membentuk pemerintahan yang akan mengurus dan melayani seluruh lapisan masyarakat, serta memilih wakil rakyat untuk mengawasi jalannya pemerintahan.

Perwujudan kedaulatan rakyat dilaksanakan melalui Pemilu sebagai sarana bagi rakyat untuk memilih pemimpin melalui pemilihan Presiden dan Wakil Presiden yang dipilih dalam satu pasangan secara langsung serta memilih wakilnya yang akan menjalankan fungsi melakukan pengawasan, menyalurkan aspirasi politik rakyat, membuat undang-undang sebagai landasan bagi semua pihak di Negara Republik Indonesia dalam menjalankan fungsi masing-masing, serta merumuskan anggaran pendapatan dan belanja untuk membiayai pelaksanaan fungsi-fungsi tersebut ${ }^{22}$. Karena itu, begitu mulia suara rakyat (pemilih) untuk menentukan keberlangsungan penyelenggaraan negara. Kewajiban dan negara untuk menjamin terfasilitasinya hak konstitusional seluruh warga negara untuk dapat memilih pada Pemilihan Kepala

\footnotetext{
21 Jimly Asshiddiqie, Menuju Negara Hukum Yang Demokratis, Jakarta: Bhuana Ilmu Populer, 2009, hlm. 377.
} 22 Penjelasan Umum UU RI Nomor 7 Tahun 2017. 
Daerah, Pemilihan Anggota Legislatif maupun Pemilihan Presiden dan Wakil Presiden.

Konsep memilih dalam pemilu di Indonesia dimaknai sebagai hak warga negara bukan kewajiban, sehingga sangat tergantung kepada pemilihnya apakah akan menggunakan haknya atau sebaliknya. Itulah sebabnya hampir setiap momentum pelaksanaan pemilu maupun pemilihan kepala daerah tingkat golput (tidak memilih) masih cukup tinggi.

Penyelenggaraan pemilu tidak mungkin dipisahkan dari keterlibatan warga negara sebagai pemilih maupun calon yang akan dipilih. Lebih dari itu pemilu diselenggarakan sebagai manifestasi prinsip persamaan di muka hukum (equality before the law) dan kesempatan dalam pemerintahan (equal opportunity principle ${ }^{23}$.

Hak memilih adalah pengewajantahan hak atas kesempatan yang sama dalam hukum dan pemerintahan sebagaimana diatur dalam Pasal 27 ayat (1) serta Pasal 28D ayat (1) dan ayat (3) Undang-Undang Dasar Negara Republik Indonesia Tahun 1945 (UUD NRI Tahun 1945), dan diatur lebih lanjut dalam UU Nomor 39 Tahun 1999 tentang Hak Asasi Manusia. Jaminan hak memilih (rights vote) yang secara eksplisit dirumuskan Pasal 43 ayat (1) dalam UU No. 39 Tahun 1999, menegaskan bahwa:

"Setiap warga negara berhak untuk dipilih dan memilih dalam pemilihan umum berdasarkan persamaan hak melalui pemungutan suara yang langsung, umum, bebas, rahasia, jujur, dan adil sesuai dengan ketentuan peraturan perundangundangan."

Dalam menjalankan hak dan kebebasannya, setiap orang wajib tunduk kepada pembatasan yang ditetapkan dengan undang-undang dengan maksud semata-mata untuk menjamin pengakuan serta penghormatan atas hak dan kebebasan orang lain dan untuk memenuhi tuntutan yang adil sesuai dengan pertimbangan moral, nilainilai agama, keamanan, dan ketertiban umum dalam suatu masyarakat demokratis ${ }^{24}$. Lebih lanjut Undang-Undang Nomor 7 Tahun 2017 tentang Pemilu 25 mengatur

\footnotetext{
23 Irvan Mawardi, Dinamika Sengketa Hukum Administrasi di Pemilukada: Mewujudkan Electoral Justice dalam kerangka Negara Hukum Demokratis, Yogyakarta: Rangkang Edocation, 2014, hlm. 3.

24 Pasal 28 J UUD NRI Tahun 1945.

${ }^{25}$ Sebelumnya pengaturan pemilu dipisahkan antara pemilu DPR, DPD, DPRD Provinsi dan DPRD Kabupaten/Kota dengan Pemilu Presiden dan Wakil Presiden serta pengaturan Penyelenggara Pemilu. Sekarang melalui UU RI No. 7 Tahun 2017 diatur dalam satu kodifikasi.
} 
penyelenggaraan pemilihan umum (Pemilu), yang terdiri atas pemilu untuk memilih DPR, DPD, DPRD Provinsi dan DPRD Kabupaten/Kota serta memilih Presiden dan Wakil Presiden yang dilaksanakan serentak mulai tahun 2019. Sedangkan pelaksanaan Pemilihan Kepala Daerah (Pilkada) baik di tingkat Provinsi maupun di tingkat Kabupaten/Kota diatur tersendiri yakni UU Nomor 10 Tahun 2017 perubahan terakhir atas UU Nomor 8 Tahun 2015. Secara teknis pelaksanaan Pemilu maupun Pilkada diatur melalui Peraturan Komisi Pemilihan Umum (PKPU) dan teknis pengawasan melalui Peraturan Badan Pengawas Pemilihan Umum (Perbawaslu) dimana penyusunan PKPU maupun Perbawaslu terlebih dahulu wajib berkonsultasi dengan $\mathrm{DPR}^{26}$. Perubahan regulasi terkait dengan kepemiluan sangat dinamis bahkan setiap momentum Pemilu (5 tahun) terjadi perubahan terhadap UU Pemilu dan Pilkada27.

Pelaksanaan Pemilu dan Pilkada secara langsung (one man, one vote) memberikan kesempatan kepada seluruh warga negara untuk menggunakan hak pilih secara Langsung, Umum, Bebas, Rahasia (Luber) dan Jujur dan Adil (Jurdil). Namun, warga masyarakat yang akan menggunakan hak pilih dibatasi dengan persyaratan-persyaratan adminsitrasi. Pembatasan tersebut diatur dalam UU Pemilu dan Pilkada serta peraturan teknis KPU. Persyaratan untuk dapat menggunakan hak pilih antara lain terkait usia pemilih, domisili pemilih, harus terdaftar sebagai pemilih. Penyelenggara Pemilu diberikan kewajiban untuk memastikan terpenuhinya persyaratan tersebut.

Salah satu persyaratan untuk memilih yang krusial adalah terdaftar sebagai pemilih. Proses menuju penetapan daftar pemilih melalui jalur yang cukup panjang, bermula dari Daftar Agregat Kependudukan (DAK) yang di susun oleh Pemerintah lalu diserahkan kepada penyelenggara pemilu (KPU). Selanjutnya KPU melakukan sinkronisasi dengan data pemilih terakhir yang kemudian menghasilkan Daftar

26 Konsultasi Peraturan KPU dengan DPR tidak lagi bersifat mengikat setelah keluarnya Putusan MK Nomor 92/PUU-XIV/2016.

27 Kurun waktu kurang dari 5 tahun, UU Pilkada dilakukan perubahan 4 (empat) kali, yakni terhadap UU No. 32 Tahun 2004 terkait dengan Pilkada menjadi UU Nomor 22 Tahun 2014, dalam UU ini mengatur mekanisme pemilihan kepala daerah secara tidak langsung melalui DPRD. Dengan pertimbangan UU ini mendapat penolakan yang luas oleh rakyat dan proses pengambilan keputusannya telah menimbulkan persoalan serta kegentingan yang memaksa sesuai Putusan Mahkamah Konstitusi Nomor 138/PUU-VII/2009 selanjutnya dikeluarkan Peraturan Pemerintah Pengganti Undang-Undang RI Nomor 1 Tahun 2015 tentang Pemilihan Gubernur, Bupati, dan Walikota. Pada tahun yang sama disahkan UU RI No. 1 Tahun 2015 tentang Penetapan Perpu No. 1 Tahun 2014 tentang Pemilihan Gubernur, Bupati, dan Walikota menjadi UU. Pada tahun 2015 dilakukan perubahan melalui UU Nomor 8 Tahun 2015 selanjutnya perubahan kedua dengan UU Nomor 10 Tahun 2016. 
Potensial Pemilih Pemilu (DP4). KPU melalui jajarannya di tingkat bawah melakukan pemutakhiran data pemilih untuk memastikan keberadaan nama-nama yang ada dalam DP4 serta kemungkinan ada warga masyarakat yang belum tercatat, pindah domisili, meninggal dunia, anggota TNI, POLRI. Langkah selanjutnya dilakukan pengumuman sebagai daftar pemilih sementara (DPS) terakhir setelah ada perbaikan ditetapkanlah daftar pemilih tetap (DPT) Pemilu atau Pilkada. DPT inilah yang akan menjadi dasar KPU untuk menyiapkan logistik pemilu dan warga masyarakat yang dapat menggunakan hak pilihnya. ${ }^{28}$ Proses tersebut menggambarkan bahwa begitu rumitnya penyediaaan data pemilih untuk Pemilu maupun Pilkada yang akurat.

Data pemilih yang tidak valid (akurat) menjadi problem klasik yang dihadapi pada setiap momentum penyelenggaran pemilu, bagi warga negara yang mempunyai hak pilih namun tidak terdaftar sebagai pemilih merasa hak konstitusional untuk memilih terhalangi. Bagi peserta pemilihan yang kalah, data pemilih yang tidak akurat sering dijadikan alasan hukum dalam dalil gugatan ke Mahkamah Konstitusi29. Kedaulatan rakyat untuk memilih dapat tersandra pelaksanaannya karena alasan prosedural dan teknis administrasi penyusunan pemilih yang tidak akurat.

Selain DPT Pemilu yang menjadi standar umum dalam UU Pemilu untuk dapat menggunakan hak pilih, adalah syarat domisili pemilih yang merujuk pada Kartu Keluarga (KK) dan Kartu Tanda Penduduk (KTP). Bagi masyarakat dalam wilayah sengketa batas daerah yang muncul dari akses pemekaran wilayah menyembabkan terjadi ketidakpastian domisili. Pada akhirnya pada saat pelaksanaan pemilu berpotensi tidak mendapatkan kesempatan untuk menggunakan hak pilih karena belum mendapatkan kepastian hukum wilayah domisili yang jelas sebab masih dalam sengketa.

Syarat domisili dan dokumen kependudukan sebagai basis penetapan DPT telah menimbulkan ketidakpastian dan jaminan untuk memilih pada pelaksanaan Pemilu dan Pilkada bagi masyarakat 6 (enam) Desa yang terlibat sengketa batas. Masyarakat yang secara faktual berada di wilayah sengketa tersebut masih banyak

28 Putusan MK No. 102/PUU-VII/2009. Intinya bagi warga negara yang memenuhi syarat memilih namun tidak terdapat dalam DPT dapat menggunakan hak pilih dengan menggunakan KTP atau paspor yang mash berlaku. 29 Putusan MK No. 36/PHP.GUB-XVI/2018. Gugatan Prabowo-Hatta ke MK pada saat Pilpres 2014 dalam materi gugatannya mempersoalkan data pemilih yang dinilai tidak akurat. Dapat juga dilihat materi gugatan PHP Pilgub Malut tahun 2018 yang mempersoalkan DPT yang tidak valid. 
yang tidak dapat menggunakan hak pilihnya karena tidak terfasilitasinya oleh penyelenggara Pemilu.

\subsection{Implikasi Penyelenggaraan Pemilu dan Pilkada di 6 (Enam) Desa Yang Bersengketa Batas Wilayah}

Pada saat pelaksanaan Pemilihan Gubernur dan Wakil Gubernur Maluku Utara Tahun 2013, penetapan DPT masyarakat 6 (enam) Desa dilakukan oleh KPUD Kabupaten Halmahera Utara, namun terjadi penolakan oleh sebagian warga. Selanjutnya KPUD membentuk 2 TPS dalam satu Desa masing-masing untuk memfasilitasi warga yang menginginkan menggunakan hak pilihnya di Kabupaten Halmahera Utara begitu juga TPS khusus untuk warga yang menginginkan memilih di Kabupaten Halamahera Barat ${ }^{30}$. Langkah ini dinilai sebagai terobosan yang dilakukan oleh penyelenggara pemilu untuk menjamin dan memfasilitasi keinginan masyarakat menggunakan hak pilihnya. Namun upaya tersebut tidak berhasil meningkatkan partisipasi pemilih karena tetap saja masayarakat yang menginginkan difasilitasi penyelenggaraannya oleh KPUD Kabupaten Halmahera Barat.

Tindakan penyelenggara pemilu memberikan jalan keluar (emergency exit) merupakan langkah progresif yang tepat, walaupun hukum pemilu tidak mengatur dualisme TPS untuk lintas Kabupaten. Fungsi utama hukum yaitu untuk melayani manusia. Setiap kali fungsi hukum itu terusik maka kita perlu melakukan sesuatu yang kreatif untuk mengatasinya ${ }^{31}$. Apalagi menyangkut hak masyarakat dijamin dalam konstitusi sebagai hak asasi. Dalam pandangan hukum progresif Satjipto Rahardjo bahwa hukum bukanlah teks mati, bukan pula instrumen kaku penguasa untuk mengimplementasikan kehendaknya tanpa melihat realitas sosial dan kebutuhan rakyatnya. Penghambatannya adalah cara-cara berhukum yang hanya dengan menjaga teks Undang-Undang ${ }^{32}$.

Bila ditinjau dari aspek pendekatan hasil pemlihan, secara substansi perhitungan suara pada pemilihan Gubernur dan Wakil Gubernur akan diakumulasi (jumlahkan) di tingkat Provinsi sehinga tidak mempengaruhi bila pemilih yang menggunakan hak pilihnya di lintas Kabupaten/Kota dalam wilayah Provinsi bersangkutan. Kondisi ini sangat berbeda ketika pemilihan legislatif untuk memilih

\footnotetext{
30 Laporan hasil pengawasan Bawaslu Maluku Utara Tahun 2014. Sumber : Sekretariat Bawaslu Maluku Utara.

31 Satjipto Rahardjo, Ilmu Hukum di Tengah Arus Perubahan, Malang: Surya Pena Gemilang, 2008, hlm. 18.

32 Ibid., hlm. 119.
} 
anggota Dewan Perwakilan Rakyat Daerah Provinsi/Kabupaten (DPRD Provinsi dan DPRD Kabupaten). Sistem yang digunakan adalah pembagian Daerah Pemilihan (Dapil) yang berbasis pada wilayah Kecamatan.

Pada pelaksanaan pemilu legislatif dan Pilpres tahun 2014, KPU Provinsi Maluku Utara menetapkan bahwa 6 (enam) Desa hanya akan difasilitasi penyelenggaraannya oleh KPUD kabupaten Halmahera Utara. Sikap KPU ini kembali mendapat reaksi dari masyarakat dengan menghalangi petugas pemutakhiran data pemilih (PPDP) untuk melakukan pendataan. Atas penolakan tersebut KPU Provinsi mengambil inisiatif memfasilitasi pemutakhiran dengan membentuk tim khusus dari unsur KPUD, Bawaslu dan Partai Politik. Pelaksaan pemutakhiran data pemilih dapat dikatakan under presure karena melibatkan aparat kemanan. Pemutakhiran data pemilih yang biasanya hanya dilakukan oleh seorang Petugas Pemutakhiran Data Pemilih (PPDP) yang berada dalam lingkungan RT/RW setempat. Namun, tidak terjadi pada pemutakhiran di wilayah 6 (enam) Desa tersebut. Pengawalan ketat dari pihak kepolisian ini cukup beralasan, karena ada ancaman dari masyarakat yang menolak untuk dilakukan pemutakhiran data jika dilakukan oleh petugas dari KPUD Kabupaten Halmahera Utara ${ }^{33}$. Kondisi ini mencerminkan bahwa pelaksanaan tahapan pemilu di wliayah 6 (enam) Desa yang terlibat sengketa batas wilayah jauh dari prinsip penyelenggaran pemilu yang partisipatif.

Hasil pelaksanaan pemutakhiran data pemilih di 6 (enam) Desa pada Pemilu tahun 2014 yang ditetapkan oleh KPU Kabupaten Halmahera Utara, dapat dilihat pada tabel berikut:

Tabel 1.

Daftar Pemilih Tetap 6 (enam) Desa Pemilu Tahun 2014

\begin{tabular}{|c|c|c|c|}
\hline \multirow{2}{*}{ No } & \multirow{2}{*}{ Nama Desa } & Kab. Halbar & Kab. Halut \\
\cline { 3 - 4 } & & Jumlah Pemilih Terdaftar & Jumlah Pemilih Terdaftar \\
\hline 1 & Pasir Putih & 187 & 259 \\
\hline 2 & Bobane Igo & 668 & 283 \\
\hline 3 & Tetewang & 465 & 267 \\
\hline
\end{tabular}

33 Pelaksanaan pemutakhiran data pemilih di wilayah 6 (enam) Desa, petugas pemutakhiran dari KPUD dibentuk tim khusus masing-masing dikawal 10 personil kepolisian dari Polda Malut, kondisi ini membuat Pelaksanaan Pemilu yang tidak lazim yakni mencekam menyebabkan masyarakat tertekan secara psikis. 


\begin{tabular}{|c|c|c|c|}
\hline 4 & Akelamo Kao & 340 & 801 \\
\hline 5 & Gamsungi & 188 & 145 \\
\hline 6 & Dum-Dum & 230 & 183 \\
\hline \multicolumn{2}{|c|}{ Jumlah: } & 2078 & 1938 \\
\hline
\end{tabular}

Sumber Data: KPU Kabupaten Halmahera Utara.

KPU Halmahera Utara mengklasifikasi DPT menjadi 2 (dua) versi yakni, versi Halmahera Utara dan versi Halmahera Barat didasarkan hasil verifikasi data secara faktual. Dari data tersebut menunjukan begitu besar jumlah pemilih yang tidak terfasilitasi untuk menggunakan hak pilih karena secara de facto $^{34}$ menghedaki masuk ke wilayah Kabupaten Halmahera Barat. Sedangkan di sisi lain, KPU hanya memfasilitasi masyarakat 6 Desa dengan membentuk tempat pemungutan suara oleh penyelenggara KPPS di wilayah Halmahera Utara.

Data Tabel 1 di atas, menggambarkan bahwa penyelenggara pemilu melegitimasi hasil pemutakhiran data pemilih menjadi 2 (dua) versi dengan memberikan keterangan pada Daftar Pemilih Tetap (DPT) yang ditetapkan oleh KPUD Kabupaten Halmahera Barat, pertama yang berdomisili di wilayah Kabupaten Halmahera Utara sebanyak 1938 orang dan yang berkedudukan di wilayah Kabupaten Halmahera Utara sebanyak 2078 orang, total jumlah pemilih di 6 (enam) Desa tersebut sebanyak 4014 jiwa pilih.

Pada saat pemilihan Gubernur dan Wakil Gubernur Tahun 2018, daerah 6 (enam) Desa tetap difasilitasi dalam wilayah adminitrasi Kabupaten Halmahera Utara. Namun, bukan berarti pelaksanaannya tanpa masalah. Gelombang protes masyarakat terhadap penyelenggara pemilu dalam bentuk blokade jalan lintas Halmahera dan menolak menggunakan hak pilihnya ${ }^{35}$. Akibatnya berpengaruh pada tingkat partisipasi pemilih.

Adapun perbandingan antara pemilih yang menggunakan hak pilih dengan yang tidak menggunakan hak pilih berdasarkan DPT yang ditetapkan oleh KPUD Halmahera Utara pada Pilkada Tahun 2018, dapat dilihat pada tabel di bawah ini:

\footnotetext{
34 Bahkan secara de jure sebagian masyarakat di 6 (enam) Desa memiliki Kartu Tanda Penduduk (KTP) di Kabupaten Halmahera Barat.

35 “Masyarakat Enam Desa Blokade Jalan Raya Sofifi-Tobelo”, diakses pada tanggal 26 April 2020.
} 
Tabel 2.

Tingkat Partisipasi Pemilih di 6 (enam) Desa pada Pilgub Tahun 2018

\begin{tabular}{|l|l|c|c|c|}
\hline \multirow{2}{*}{ No } & \multicolumn{1}{|c|}{ Desa } & DPT & \multicolumn{2}{|c|}{ Pemilih } \\
\cline { 3 - 5 } & & $\begin{array}{c}\text { Menggunakan Hak } \\
\text { Pilih + DPTB }\end{array}$ & $\begin{array}{c}\text { Tidak Menggunakan } \\
\text { Hak Pilih }\end{array}$ \\
\hline 1 & Dum-Dum & 344 & 245 & 103 \\
\hline 2 & Akelamo Kao & 897 & 395 & 506 \\
\hline 3 & $\begin{array}{l}\text { Gamsungi/Ak } \\
\text { esahu }\end{array}$ & 303 & 119 & 187 \\
\hline 4 & Tetewang & 981 & 411 & 570 \\
\hline 5 & Bobaneigo & 2146 & 952 & 1242 \\
\hline 6 & Pasir Putih & 372 & 245 & 132 \\
\hline & Total & 5043 & 2367 & 2740 \\
\hline
\end{tabular}

Sumber: Laporan Hasil Pengawasan Bawaslu Maluku Utara Tahun 2018 dan Pihak Terkait ${ }^{36}$

Berdasarkan data di atas, jumlah pemilih yang terdaftar dalam DPT sebanyak 5043 jiwa. Tingkat partisipasi pemilih sangat rendah, bahkan jumlah yang tidak menggunakan hak pilihnya lebih besar dari jumlah yang menyalurkan hak pilihnya. Kondisi ini sudah diprediksi sebelumnya karena telah terjadi penolakan masyarakat terhadap penyelenggaraan yang dilakukan oleh petugas jajaran KPUD Halmahera Utara. Sebagian besar warga yang tidak menggunakan hak pilihnya adalah warga yang menolak masuk di wilayah Halmahera Utara.

Berdasarkan laporan hasil pengawasan Bawaslu, menjelang pelaksanan pungut hitung, KPU Provinsi dan KPU Kabupaten Halmehara Utara telah berusaha maksimal mendistribusikan Form C6 (undangan memilih) sesuai dengan jumlah DPT yang terdaftar di 6 (enam) Desa tersebut. Penyelenggara pemilu KPU, Bawaslu dan stakeholder sehari sebelum hari pemungutan suara telah melakukan upaya agar masyarakat 6 (enam) Desa dapat menggunakan hak pilihnya ${ }^{37}$. Penyelenggara terkesan "memaksakan" menetapkan DPT masyarakat 6 (enam) Desa masuk ke wilayah Halmahera Utara. Di sisi lain secara faktual mengabaikan fakta bahwa sebagian masyarakat 6 (enam) Desa memiliki KTP Halmahera Barat.

\footnotetext{
36 Laporan Bawaslu dan Pihak Terkait yang termuat dalam Putusan MK Perkara Nomor: 36/PHP.Gub-XVI/2018., hlm. 729.

37 Ibid., hlm. 728.
} 
KPU dalam melaksanakan tugasnya bersifat mandiri ${ }^{38}$ dan menjadi leading sektor penyelenggaraan pemilu, keberadaannya untuk menjamin pemilu berintegritas jujur dan adil yang berdasarkan asas langsung, umum, bebas dan rahasia, jujur dan adil. Karena itu sudah seharusnya orientasi penyelenggaraan pemilu menyelamatkan hak pilih warga negara.

Slogan "KPU melayani" secara subtansi diperlukan pelayanan yang menyelami rasa keadilan masyarakat. Pemilik pemilu adalah rakyat ketika terganggunya hak konstitusionalnya untuk memilih yang disebabkan teknis administrasi, maka penyelenggara pemilu wajib hadir memberi ruang agar pemilih mendapatkan keadilan. KPU dapat mengisi kekosongan hukum (rechts vacuum) untuk menyelamatkan hak pilih warga negara di daerah konflik batas wilayah. Di tengah problem penerapan hukum yang belum memberikan rasa keadilan bagi masyarakat, maka diperlukan pihak yang mempunyai otoritas mengambil langkah untuk menjamin rasa keadilan masyarakat, di sinilah dibutuhkan penyelenggara pemilu yang berparadigma hukum pemilu.

Dalam upaya untuk menjamin hak memilih warga negara, maka dibutuhkan paradigma hukum progresif sehingga dapat menjamin terwujudnya kedaulatan rakyat melalui pemilu dengan berorentasi pada hakekat dilaksanakannya pemilu sebagaimana diatur dalam konstitusi. Secara substansi aturan yang mengatur pemilu berorentasi pada terpenuhinya hak memilih (right to vote). Ketentuan yang merupakan prosedur administratif idealnya tidak menegaskan hal-hal yang bersifat substansial yaitu hak warga negara untuk memilih dalam pemilihan umum.

Salah satu cara untuk menjamin terpenuhinya hak memilih (right to vote) melalui penyediaan data pemilih dengan melibatkan penyelenggara pemilu satu tingkat di atas dalam hal terjadi sengketa wilayah. Penyediaan data pemilih oleh penyelenggara satu tingkat di atasnya ini dengan model konektifitas data pemilih antara dua Kabupaten yang bersengketa batas maka, memungkinkan setiap pemilih dapat menggunakan hak pilihnya, sepanjang masih dalam satu wilayah pemilihan yakni wilayah Provinsi. Sebagai contoh, pada Pemilihan Gubernur dan Wakil Gubernur dalam hal ini leading sektor penyelenggara adalah KPU Provinsi, maka

38 KPU bersifat mandiri menegaskan bahwa KPU dalam menyelenggarakan Pemilihan Umum bebas dari pengaruh pihak manapun. 
penetapan Daftar Pemilih Tetap (DPT) pada daerah yang sedang bersengketa batas wilayah dalam hal ini Kab. Halbar dan Kab. Halut dilakukan oleh penyelenggara Pemilu satu tingkat di atasnya yaitu KPU Provinsi. Demikian pula dengan pelaksanaan teknis pemilihan di bawah kendali langsung oleh KPU Provinsi. Namun demikian, secara teknis pelaksanaannya di wilayah sengketa batas dapat melibatkan KPU Kabupaten. Model seperti ini akan dapat meminimalisir terjadinya konflik dan penolakan warga serta dapat meningkatkan partisipasi pemilih. Pada sisi lain, upaya tersebut perlu dilakukan agar penyelenggara pemilu dapat menjamin dan memfasilitasi hak konstitusional warga negara untuk memilih dan dipilih.

\subsection{Perlakuan Khusus Hak Memilih di Wilayah Sengketa Batas sebagai Ius Constituendum}

Pemekaran Daerah secara yuridis dimaksudkan untuk meningkatkan pelayanan publik, kesejahteraan rakyat, dan memperkokoh NKRI tapi dalam tahap implementasi ternyata masih "jauh panggang dari api", dan sekelumit persoalan yang disebabkan oleh sengketa wilayah yang telah diuraikan sebelumnya merupakan bukti yang tidak dapat disangkal. Belum tuntasnya proses delimitasi wilayah pemerintah daerah di Indonesia menyebabkan batas wilayah antar pemerintah daerah tumpang-tindih. Kondisi tersebut berdampak terhadap kehidupan sosial politik masyarakat di wilayah tersebut. Dampak paling dirasakan oleh masyarakat adalah tidak dapat menggunakan hak pilih secara langsung, bebas dan rahasia.

Konflik batas wilayah di 6 (enam) Desa di Maluku Utara yang dipicu dari pemekaran wilayah melalui UU Nomor 1 Tahun 2003 diprediksi akan terus berlanjut. Berbagai upaya yang telah dilakukan selama ini oleh Pemerintah Daerah maupun Pusat namun belum mampu menyelesaikan sengketa yang ada. Oleh karena itu UU No 1 Tahun 2003 dan turunannya yang mengatur pemekaran wilayah khususnya di 6 (enam) Desa yang terlibat konflik tidak berjalan secara efektif.

Dalam perspektif teori efektifitas hukum suatu peraturan dikatakan efektif dalam arti "keberlakuan" menurut Meuwissen ${ }^{39}$ haruslah memenuhi 3 (tiga) syarat yakni: keberlakuan sosial atau faktual, keberlakuan yuridis, dan keberlakuan moral.

\footnotetext{
39 Arif Sidharta, Meuwissen tentang Pengembangan Hukum, Ilmu Hukum, Teori Hukum, dan Filsafat Hukum,
} Bandung: Rafika Aditama, 2009, hlm. 46-47. 
entuk yang pertama, keberlakuan sosial atau faktual ini berkaitan dengan kaidah hukum tersebut dalam kenyataannya diterima dan diberlakukan oleh masyarakat umumnya. Kedua, keberlakuan yuridis. Aturan hukum tersebut dibuat melalui prosedur yang benar dan tidak bertentangan dengan peraturan lainnya. Meuwissen lebih lanjut menjelaskan bahwa suatu kaidah hukum yang secara yuridikal sah dapat tidak memiliki (kehilangan) kepatuhan faktual. Dalam hal demikian, maka ia kehilangan keberlakuannya. Ketiga adalah suatu kaidah hukum kehilangan keberlakuan moralnya, bentuk keberlakuan dititikberatkkan pada persoalan kualitas (legitimasi) dari hukum. Lebih lanjut Meuwissen ${ }^{40}$ membedakan antara keberlakuan idiil dan keberlakuan normatif. Tiga bentuk keberlakuan sebagaimana diuraikan di atas adalah bentuk keberlakuan normatif yang harus selalu diperhitungkan, ketigatiganya harus ada, mereka adalah unsur-unsur konstitutif dari keberlakuan hukum. Jika salah satu (atau lebih) dari tiga momen itu tidak ada, maka hilanglah keberlakuan dari hukum itu. Bila pendapat Meuwissen di atas dikaitkan dengan keberadaan UU Nomor 1 Tahun 2003 serta Permendagri No. 137 Tahun 2017 serta Permendagri No. 60 Tahun 2019 yang berkaitan dengan pemekaran wilayah Kecamatan dan batas wilayah tidak berlaku efektif karena terdapat penolakan oleh masyarakat yang dilakukan secara terstruktur dan masif. Penolakan tersebut muncul setiap momentum pelaksaan pemilu. Begitu juga dengan sikap kedua Pemerintah Daerah yang masih tetap memfasilitasi secara bersamaan terhadap 6 (enam) Desa antara Kab. Halbar dan Kab. Halut. Hal ini mengambarkan bahwa secara nyata terjadi penolakan terhadap politik hukum pemekaran wilayah yang dilegitimasi melalui peraturan perundang-undangan, sehingga diperlukan peninjauan ulang dengan mempertimbanngkan aspek sosiologis masyarakat setempat.

Sedangkan pada aspek penyelenggaraan Pemilu dan Pilkada di 6 (enam) Desa, belum adanya payung hukum yang jelas untuk melindungi pemilih di wilayah sengketa. Kondisi ini telah menyebabkan hilangnya hak konstitusional memilih masyarakat 6 (enam) Desa yang telah berlangsung berulang dari pemilu ke pemilu. Fakta tersebut diperkuat dengan adanya putusan Mahkamah Konstitusi Nomor 36/PHP.GUB-XVI/2018 yang memerintahkan untuk dilakukan Pemungutan Suara

40 Ibid., hlm. 48. 
Ulang (PSU) ${ }^{41}$ di seluruh TPS 6 (enam) Desa dengan dasar pertimbangan ada fakta hukum yang tidak bisa diabaikan bahwa sejumlah 2.494 warga tidak memiliki identitas Kabupaten Halmahera Utara, atau masih menggunakan KTP kabupaten Halmahera Barat. Karena itu MK memerintahkan kepada KPU sebelum dilakukan PSU terlebih dahulu dilakukan perbaikan DPT berbasis data secara de facto sesuai dengan KTP dan Kartu Keluarga (KK) yang dimiliki oleh masing-masing pemilih. Putusan MK tersebut menegaskan bahwa hak konstitusional warga negara untuk memilih tidak boleh dihilangkan dengan alasan teknis administrasi formalistis. Kondisi faktual masyarakat patut dipertimbangkan agar hak pemilih tidak terabaikan.

Undang-Undang Nomor 7 Tahun 2017 tentang Pemilu maupun UndangUndang Nomor 8 Tahun 2015 sebagaiman telah diubah dengan Undang-Undang Nomor 10 Tahun 2017 tentang Pemilihan Gubernur dan Wakil Gubernur, Bupati/Wali Kota, belum mengatur jaminan perlindungan hak pilih masyarakat di wilayah sengketa batas seperti pada kasus 6 (enam) Desa. Kasus seperti ini berpotensi terjadi di daerah lain seiring pemekaran wilayah otonom baru. Ketentuan dalam regulasi Pemilu dan Pilkada terkait dengan syarat-syarat untuk dapat menggunakan hak pilih berbasis domisili yang dibuktikan dengan dokumen kependudukan dan terdaftar sebagai pemilih. Sehingga ketentuan tersebut belum mengakomodir eksistensi masyarakat yang secara faktual berdomisili di wilayah sengketa batas.

Perlunya pengaturan tentang perlakuan khusus dalam UU Pemilu dan Pilkada sebagai bentuk tanggungjawab negara dalam pemenuhan hak politik warga negara untuk memilih. Menurut Manfred Nowak, terdapat tiga kewajiban negara kaitannya dengan hak asasi manusia yaitu, kewajiban untuk menghormati (to respect), kewajiban untuk melindungi (to protect), dan kewajiban negara untuk memenuhi (to fulfill) ${ }^{42}$. Dalam kaitan kewajiban negara untuk melindungi (to protect) warga negara dari hilangnya hak untuk menggunakan hak pilihnya yang disebabkan karena alasan prosedural administrasi maka, diperlukan hadirnya negara memberikan

41 Putusan MK No. 36/PHP.GUB-XVI/2018. Pertimbangan, hlm. 804.

42 Manfred Nowak, Pengantar pada Rezim HAM Internasional, (Diterjemahkan dari Manfred Nowak, Introduction to the International Human Rights Regime), Jakarta: Raoul Wallenberg Institut of Human Rights and Humanitarian Law bekerjasama dengan Departemen Hukum dan HAM Indonesia, 2003, hlm. 51. 
perlindungan hukum yang memadai dalam peraturan perundang-undangan. Jaminan perlindungan hukum terhadap warga negara di wilayah sengketa adalah bentuk negara memenuhi (to fulfill) hak warga negaranya.

Selain itu, adanya pengaturan terkait penyelenggaraan Pemilu di wilayah sengketa batas akan terwujud kepastian hukum bagi penyelenggara (KPU) dalam menjalankan tahapan di wilayah tersebut. Pada sisi lain, pengaturan perlakuan khusus diperlukan untuk melindungi hak konstitrusional warga negara sebagai pengejawantahan hak atas kesempatan yang sama dalam hukum dan pemerintahan yang dijamin dalam UUD 1945 Pasal 27 Ayat (1) serta Pasal 28D ayat (1) dan ayat (3).

Pengaturan perlakuan khusus tersebut dapat dicantumkan secara eksplisit dalam UU Pemilihan dan Pilkada, sedangkan secara teknis diatur dalam PKPU. Adapun materi muatan yang perlu diatur antara lain berkaitan dengan status domisili pemilih di wilayah sengketa batas haruslah berbasis kondisi faktual. Dengan demikian, adanya pengaturan perlakuan khusus pelaksanaan hak pemilih di wilayah sengketa batas akan meningkatkan partisipasi masyarakat dalam Pemilu sekaligus wujud tanggungjawab negara terhadap hak warga negaranya.

\section{PENUTUP}

\subsection{Kesimpulan}

Secara umum perlindungan hak untuk memilih dan dipilih dijamin dalam Undang-Undang Dasar Negara Republik Indonesia Tahun 1945 yakni, Pasal 27 ayat (1) serta Pasal 28D ayat (1) dan ayat (3), Pasal 28H Ayat (2). Lebih lanjut diatur dalam UU Nomor 39 Tahun 1999 tentang Hak Asasi Manusia, UU Pemilu dan UU Pilkada. Sedangkan pada tataran teknis diatur melalui Peraturan Komisi Pemilihan Umum. Namun demikian, pada tataran praktikal terdapat fakta bahwa masih ada masyarakat yang berada di daerah sengketa batas wilayah seperti di 6 (enam) Desa perbatasan Kabupaten Halbar dan Halut Provinisi Maluku Utara, tidak dapat berpartisipasi menggunakan hak pilihnya dalam Pemilu maupun Pilkada karena terbentur dengan persoalan administrasi prosedural Pemilu. Peraturan teknis terkait administrasi berkaitan dengan pendataan pemilih dan penetapan daftar pemilih 
belum mengakomodir perlindungan atas kepentingan masyarakat yang mengalami sengketa batas wilayah.

Secara administrasi pendataan pemilih dan penetapan DPT oleh penyelenggaraan Pemilu (KPU dan Bawaslu) dalam penyelenggaraan Pemilu dan Pilkada di wilayah 6 (enam) Desa yang terlibat konflik batas wilayah terkesan “dipaksakan" dengan cara menetapkan DPT masuk di wilayah Kabupaten Halmahera Utara tanpa mempertimbangkan kondisi faktual, hal ini telah menyebabkan lebih dari 2000 jiwa pilih pada Pemilu 2014 tidak dapat menyalurkan hak pilihnya. Kondisi tersebut menggambarkan bahwa penyelenggaraan Pemilu dan Pilkada di daerah yang terlibat sengkata batas wilayah dapat mendegradasi prinsip-prinsip pengelenggaraan Pemilu yang demokratis dan partisipatif.

Undang-undang Pemilu dan Pilkada dan peraturan teknis yang ada saat ini, belum mengatur secara eksplisit terkait dengan jaminan perlindungan hak warga negara untuk memilih (right to vote) di wilayah sengketa batas akibat pemekaran wilayah. Akibat belum diaturnya maka terjadi kekosongan hukum (rechts vacuum). Oleh karena itu, kewajiban negara untuk memberikan perlindungan (to protect) dan pemenuhan hak (to fulfill) untuk memilih bagi warga negara khususnya di daerah yang terjadi sengketa batas wilayah. Perlindungan tersebut melalui pengaturan khusus yang dapat menjamin terfasilitasinya hak untuk memilih di daerah yang terjadi sengketa batas wilayah.

\subsection{Saran}

Dalam upaya untuk menyelamatkan hak memilih bagi warga negara sebagai perwujudan kedaulatan rakyat yang dijamin dalam konstitusi maka, perlu payung hukum melalui pengaturan yang memberikan perlakuan khusus hak warga negara untuk memilih (right to vote) di wilayah sengketa batas. Pengaturan tersebut dapat dicantumkan secara eksplisit sebagai aturan peralihan dalam UU Pemilu dan UU Pilkada, sedangkan secara teknis diatur dalam PKPU. Materi yang perlu diatur tersebut antara lain, berkaitan dengan status domisili pemilih berbasis kondisi faktual, dan pengaturan teknis penyelenggaraannya. Dengan begitu hak pemilih di wilayah sengketa batas wilayah akan terselamatkan. 


\section{DAFTAR PUSTAKA}

\section{Buku-buku}

Arif Sidharta, Meuwissen tentang Pengembangan Hukum, Ilmu Hukum, Teori Hukum, dan Filsafat Hukum, Bandung: Rafika Aditama, 2009.

Irvan Mawardi, Dinamika Sengketa Hukum Administrasi di Pemilukada: Mewujudkan Electoral Justice dalam kerangka Negara Hukum Demokratis, Yogyakarta: Rangkang Edocation, 2014.

Jimly Asshiddiqie, Menuju Negara Hukum Yang Demokratis, Jakarta: Bhuana Ilmu Populer, 2009.

Lukman Santoso Az, Hukum Pemerintahan Daerah: Mengurai Problematika Pemekaran Daerah Pasca Reformasi di Indonesia, Yogyakarta: Pustaka Pelajar, 2014.

Manfred Nowak, Pengantar pada Rezim HAM Internasional, (Diterjemahkan dari Manfred Nowak, Introduction to the International Human Rights Regime), Jakarta: Raoul Wallenberg Institut of Human Rights and Humanitarian Law bekerjasama dengan Departemen Hukum dan HAM Indonesia, 2003.

Mukti Fajar ND dan Yulianto Ahmad, Dualisme Penelitian Hukum Normatif dan Empiris, Yogyakarta: Pustaka Pelajar, 2013.

Ni'matul Huda, Hukum Pemerintahan Daerah, Bandung: Nusa Media, 2017.

Satjipto Rahardjo, Ilmu Hukum di Tengah Arus Perubahan, Malang: Surya Pena Gemilang, 2008.

Takdir Rachmadi, Mediasi Penyelesaian Sengketa Melalui Pendekatan Mufakat, Jakarta: Raja Grafindo Persada, 2011.

Ucu Martanto, Ruang dan Konflik Wilayah: Cerita dari Enam Desa, Yogyakarta: CRCS UGM, 2012.

\section{Artikel}

Hasyim, Azis, Arya Hadi Dharmawan, dan Ambang Juanda, “Analisis Konflik Perebutan Wilayah di Provinsi Maluku Utara: Studi Kasus Perebutan Wilayah Antara Kabupaten Halmahera Barat dan Kabupaten Halmahera tentang Enam Desa", Solidarity: Jurnal Transdisiplin Sosiologi, dan Ekologi Manusia, April 2010.

Jembris Mou, "Konflik Wilayah Antara Kabupaten Halmahera Utara Dengan Kabupaten Halmahera Barat", Political Jurnal, Vol. 4, No. 1 Tahun 2015.

Qodir, Zuly dan Tunjung Laksono, "Politik Rente dan Konflik di Daerah Pemekaran: Kasus Maluku Utara”, Working Paper No. 002/JKSG/2012.

\section{Data Internet}

“Pemerintah Moratorium DOB hingga 2019", diakses pada tanggal 22 September 2018. 
“Pemda dan DPRD Halut Sepakat Tolak Permendagri No. 60 Tahun 2019", diakses pada tanggal 26 April 2020.

“Masyarakat Enam Desa Blokade Jalan Raya Sofifi-Tobelo", diakses pada tanggal 26 April 2020.

\section{Peraturan Perundang-undangan}

Undang-Undang Dasar Negara Republik Indonesia Tahun 1945.

Undang-Undang Republik Indonesia Nomor 39 Tahun 1999 tentang Hak Asasi Manusia (lembaran Negara Republik Indonesia Tahun 1999 Nomor 165).

Undang-Undang Republik Indonesia Nomor 9 Tahun 2015 tentang Perubahan Kedua Atas Undang-Undang Nomor 23 Tahun 2014 tentang Pemerintahan Daerah. (Lembaran Negara Republik Indonesia Tahun 2015 Nomor 58).

Undang-Undang Republik Indonesia Nomor 10 Tahun 2016 tentang Perubahan Kedua Undang-Undang Nomor 8 Tahun 2015 tentang Pemilihan Gubernur, Bupati, dan Walikota.( (Lembaran Negara Republik Indonesia Tahun 2016 Nomor 130).

Undang-Undang Republik Indonesia Nomor 7 Tahun 2017 tentang Pemilu. (Lembaran Negara Republik Indonesia Nomor 6109).

\section{Putusan Mahkamah Konstitusi}

Putusan MK Nomor 138/PUU-VII/2009

Putusan MK No. 102/PUU-VII/2009

Putusan MK Nomor 92/PUU-XIV/2016

Putusan MK No. 36/PHP.GUB-XVI/2018 